\title{
Bogor Regent's Leadership Style In Facing Covid-19 Pandemic: Critical Discourse Analysis
}

\author{
Ahmad Wahyudin ${ }^{1 *}$,Else Liliani ${ }^{2}$ \\ Yogyakarta State University ${ }^{1}$ \\ \{ahmadwahyudin@uny.ac.id ${ }^{1}$, else_1@uny.ac.id $\left.{ }^{2}\right\}$
}

\begin{abstract}
This study aims to find the leadership style of regional heads in dealing with the COVID-19 pandemic on the Kompas.com, Republika.com, and Tempo.com pages. The type of this research is descriptive qualitative one. The subject of this research is news on the leadership of regional heads woman in handling the COVID-19 pandemic. The research subjects focused on reporting on a female leader, namely Ade Munawaroh Yasin, Regent of Bogor, West Java Province in dealing COVID-19 in her area. The object of this research is the character and the womanly leadership style of this Bogor Regent. The data validity test used semantic validity, while reliability was obtained through intraters and interraters. The results showed that the media provided an image of the Bogor Regent's character in dealing COVID-19, i.e. as a leader who was responsive, creative, disciplined and assertive, analytical, caring, and anticipatory. Based on the characters described by the media, hes leadership style is a transformational leadership style.
\end{abstract}

Keywords: leadership style; COVID-19 pandemic

\section{Introduction}

Corona Virus Disease 19 (COVID-19) is a new disease that has become a pandemic. The disease, which first appeared in Wuhan, China, must be watched out for because the transmission of the virus is relatively fast, and it has a mortality rate that cannot be ignored, and there is no definitive therapy just yet (Susilo, et.al, 2020: 45-67). Indonesia is one of the countries that cannot detached itself from COVID-19 virus transmission.

For example, COVID-19 has created serious problems towards the economy. The largescale social restrictions or PSBB (Pembatasan Sosial Berskala Besar) is prolonged and or expanded to other cities, projected to cause national, sectoral, corporate and individual losses (Hadiwardoyo, 2020: 83-91). Social media has also played a part in the problems arising from this pandemic. It was recorded that there were approximately fifty hoax news stories from January to March 2020 (Rahayu and Sensusiyati, 2020: 60-73).

Hoax news emerged, one or other, because of the confusion of information. Djalante (2020) argues, there are gaps and limits of response in media content, from speeches and reports on government, social and mass media platforms. In addition, the chaos in handling COVID-19 in Indonesia arises because of poor testing capabilities (Al Muttaqi, 2020). 
In fact, the government has arranged a way to solve this problem. Regional quarantine or PSBB, for example, is seen as an effective way to limit the spread of COVID-19 (Yunus \& Rezki, 2020: 227-238). The government has even issued an e-university policy or online learning for students (Lestari, 2020: 49-56). Mimicking China in overcoming the pandemic by building hospitals to control this disease (Lin et.al, 2020). China, which utilizes social media platforms to provide information about personal hygiene, cough etiquette, setting up a network of health emergency centers (Chen, 2020), the Indonesian government also does.

Lafrenière (et.al 2019: 187-201) states that in facing a crisis, women's participation is needed to mobilize humanity. In line with Lafrenière, Nurhayati and Aji (2020: 81-92) stated that in this COVID-19 pandemic, women are able to stand at the forefront in saving household economic resilience, with various activism (working) that can be done as an economic affirmation effort that results in domestic and public survival. Leadership plays an effective role in assisting the identificating targets and related stakeholders, efficient stakeholder engagement management, and understanding the socio-cultural context in which disaster recovery projects take place (Lin et.al, 2016: 1-12). The involvement of women in overcoming the humanitarian crisis does not only break the power of patriarchy, but also sponsors gender equality (Hou and $\mathrm{Wu}, 2020: 1-6)$.

All regions led by district heads or female governors are currently exposed to COVID-19. The leadership of women who become regional heads in Indonesia is currently being tested in the face of non-natural disasters. One of the districts that becoming the epicenter of the spread of COVID-19 is Bogor. This district is led by a female regent, namely Ade Munawaroh Yasin. The full profile of the Bogor Regent is Hj. Ade Munawaroh Yasin, S.H., M.H. He was born in Bogor, May 29, 1968. He is also an Indonesian politician who served as Regent of Bogor since December 30, 2018. Ade Munawaroh served as a member of the Bogor Regency Legislative Board of PPP faction from 2014 to 2018.

The focus of this research is the discourse on the leadership style of regional leader women, namely Ade Munawaroh Yasin, Regent of Bogor, West Java Province, in dealing the COVID-19 pandemic in Kompas.com, Republika.com and Tempo.com pages. Ade Munawroh Yasin is one of fourteen female leaders who have become regional heads in Indonesia.

It is interesting to analyse how the Bogor Regent's leadership style in overcoming the COVID-19 pandemic by using a critical discourse analysis study. Various news which become research data are interpreted by identifying the character and style of leadership through the analysis of critical discourse model of Fairclough (1995 and 1992). One of the ways to analyse critical discourse of Fairclough's model is by analysing text at the linguistic level. Analysis at this level pays attention to diction, semantics, and sentences in a text.

\section{Method}

This research on the leadership of women regional heads in dealing with the COVID 19 pandemic on the news pages of Kompas.com, Republika.com, and Tempo.com is included in a qualitative descriptive study with a critical discourse analysis perspective. This research will operationally describe the critical discourse analysis process regarding the news text on the leadership of women regional heads in facing the COVID-19 Pandemic.

The subject of this research is the discourse on the leadership style of the Bogor Regent in dealing with the COVID-19 pandemic. News on the Kompas.com, Republika.com, and Tempo.com pages has been taken since the stipulation of COVID 19 as a national disaster based on the Decree of the President of the Republic of Indonesia number 20 about the 
determination of non-natural disasters in the spread of corona virus disease 2019 (COVID 19) as a national disaster on the 13th April 2020. The collection will end on May 13, 2020. The object of this research is the leadership style of the Bogor Regent in overcoming the COVID19 pandemic.

The data collection technique was done by observing and taking notes. Data analysis was carried out by the following steps: 1) identification of data based on the problem, 2) the tabulation process and descriptive qualitative explanation.

The validity of the data used in this study were content validity and semantics. The validity of the content is expected to be able to reveal various concepts that you want to know, namely the textual aspect of the leadership of the Bogor Regent in facing the COVID 19 pandemic. Meanwhile, the semantic validity is used by interpreting the data by considering the overall meaning to determine the literary and socio-cultural dimensions.

Reliability in this study is intrarater and interrater. Intrarater is done by looking at the data obtained repeatedly. This is done to find the maximum possible data and aspects that are relevant to the topic under study so that truly accurate data is obtained. The validity of research data on women's leadership was also obtained interrater. The validity of the data in this step is carried out by means of discussion between researchers to check the truth and interpretation that has been carried out in the study.

\section{Discussions}

At this time women have the same rights and opportunities as men in the public space. The government policy to set a minimum quota of $30 \%$ for women as a requirement for political parties in nominating legislative members is as a form of openness to women in the public space. However, Indonesian society is still very close to a patriarchal culture. This culture places women as the number two creatures after men. The space for women is synonymous with mattresses, kitchens and wells.

In fact, some names of female figures in Indonesia have held strategic positions in government, for example, as state ministers, governors, members of parliament and district heads, sub-district heads, village heads and even as president. The following is the role of Kompas, Republika, and Tempo in constructing the image of the Bogor Regent, Ade Munawaroh Yasin in overcoming the COVID-19 pandemic.

\subsection{Bogor Regent Character Image}

Various studies on gender and women's leadership styles are interesting to analyze. As a female leader, Bpati Bogor has a character that can be an example for other leaders, both men and women. Some of the characteristics of the Bogor Regent in facing the COVID-19 pandemic, namely responsive, creative, disciplined and assertive, analytical, attentive, and anticipatory.

Bogor Regent's responsive attitude can be seen when he explains that the average COVID19 patient in Bogor Regency is a community who works in DKI Jakarta because every day there are additional positive cases and the average Bogor residents who work in Jakarta. This became the concern of the Bogor Regent, various efforts were made to prevent the spread of COVID-19, such as PSBB, distribution of masks, and socialization of healthy living.

The Bogor Regent's creative action was realized by making the village safe for COVID-19 in Tambakan Village, Wates Jaya Village, Cigombong District, Bogor Regency, West Java. 
The village was officially chosen as a safe village from the corona virus or COVID-19, with various considerations made by the Bogor Regency Government.

A disciplined and firm attitude was shown by the Bogor Regent when she took firm action against residents who violated provisions related to PSBB. Vehicles entering the Bogor area with an unclear destination are ordered to make a U-turn and may not enter. For residents who do not wear masks, cannot pass. As a form of discipline, she asks that the adaptation of new habits is not interpreted as a relaxation of health protocols. She ordered residents to be more disciplined in dealing with a pandemic situation like now. Villages that are strong and able to independently protect their territory from the COVID-19 virus must be maintained.

The Bupati of Bogor demonstrated the analytical character. Since the implementation of partially proportional large-scale social restrictions (PSBB) on June 5, 2020, the Bogor Regency Government has classified 40 sub-districts in Bogor Regency based on the level of risk of transmission of the COVID-19 corona virus. There are 28 subdistricts with moderate risk and seven low-risk sub-districts, namely Tanjungsari, Tenjo, Tenjolaya, Sukamakmur, Sukajaya, Cijeruk, and Jasinga. The Regent of Bogor has calculated using six variables to obtain the results of the alert level at the sub-district level in the low, medium and high categories. Ade Yasin said, the effective reproduction rate for Bogor Regency is still 1.2 points based on Bappenas, so that it cannot carry out the new normal phase or the new normal, where the effective reproduction rate must be below 1 point.

As a form of her concern towards the residents, the Bogor Regent is very supportive of the declaration of a safe COVID-19 village in Cigombong District. She supported various activities in the village, such as the mask distribution movement and massive socialization about masks and how to use them properly.

The Regent of Bogor carried out an anticipatory character by continuing to make efforts to reduce the reproductive rate. Emphasis is made through increasing the number of rapid tests and swab tests in crowded locations, tracking, and constantly conducting mandatory use of masks campaigns.

\subsection{Bogor Regent's Transformational Leadership Style}

The character of the Bogor Regent in facing the COVID-19 pandemic shows her leadership style. The leadership style seen is a transformational leadership style. Ade Munawaroh Yasin optimally transforms various kinds of efforts made to achieve goals in accordance with predetermined targets. There is a visible sense of pride, trust, admiration, and loyalty from her followers. The leadership of the Bogor Regent shows that there are changes in values, beliefs, attitudes, behaviours, emotions, and needs of subordinates for better changes in the future. Transformational leaders are leaders who inspire their followers to put their personal interests aside for the good of the organization and are able to have a tremendous influence on their followers (Danim, 2004: 54, Yukl, 2010: 313, Triantoro, 2004: 62, Robbins and Judge, 2008: 90). The Bogor Regent's transformational leadership style has the following characteristics.

\subsection{Idealized Influence}

The Bogor Regent has an ideal influence in carrying out his leadership. This can be seen from the sense of pride, respect and trust of the people. This ideal influence is also known as a charismatic leader because followers have deep confidence in their leader, feel proud to be able to work with their leader, and trust in the leader's capacity to solve every problem. As a leader who has ideal influence can be seen in the following news excerpt. 
REPUBLIKA.CO.ID, BOGOR - One of the residents of Tambakan Village, Baim (25 years) admitted that he is very happy that his village was chosen as a safe location for COVID-19. "It is quite appreciated, let alone the Regent's attention. What is certain is that this achievement should not let us decrease health care and protocols after receiving this, " said Baim.

A similar statement was also conveyed by Cigombong Sub-district Head, Minarso, who felt very proud of the choice of Kampung Tambakan. "What is certain is that I am the same as the Regent (Ade Yasin). Highly appreciates the community regarding the safe village of COVID-19. Proud and definitely happy, "said Minarso.

\subsection{Inspirational Motivation}

The Regent of Bogor is a leader who is able to communicate a variety of high expectations, convey a variety of interesting work programs. He enthusiastically communicates various kinds of efforts and solutions in dealing with the COVID-19 pandemic so that he can foster team spirit, not just individual enthusiasm. A very interesting work program from Ade Munawaroh Yasin is to create examples of villages that are safe from COVID-19.

REPUBLIKA.CO.ID, BOGOR - Bogor Regent Ade Munawaroh Yasin inaugurated a safe village for COVID-19 in Tambakan Village, Wates Jaya Village, Cigombong District, Bogor Regency, West Java on Wednesday (26/8). The village was officially chosen as a safe village from the corona virus or COVID-19, with various considerations made by the Bogor Regency Government

\subsection{Intellectual Stimulation}

In facing the COVID-19 pandemic, the Bogor Regent was able to increase the intelligence of his subordinates to increase their creativity and innovation, increase rationality, and solve problems carefully. He tries to build team and community attention and awareness in dealing with problems by using new approaches or perspectives. Following are the various efforts made by Ade Munawaroh Yasin and his subordinates in overcoming COVID-19 in their region.

REPUBLIKA.CO.ID, BOGOR - "We continue to make efforts to reduce reproduction rates, through increasing the number of rapid tests and swab tests in crowded locations, tracking, requiring the use of masks and other efforts, " said Ade Yasin.

JAKARTA, KOMPAS.com - Ade said that his party would be more assertive in taking action against residents who violated provisions related to PSBB. "For example, a vehicle enters Bogor but the destination is also unclear or going home, they are told to make a $U$ turn so they cannot enter our area," said Ade. "For those who violate the masks rules are also treated the same, they should not cross, because wearing masks in all red areas are mandatory," he said.

\subsection{Individualized Consideration}

The Bogor Regent is a leader who pays personal attention. She cares for and treats her subordinates individually, as well as trains and advises. As a leader, she invites members to realize the abilities of others and develop the potential that exists in each member. The following is an excerpt from the news which shows that Ade Munawaroh Yasin pays attention to her community. 
JAKARTA, KOMPAS.com - Bogor Regent Ade Yasin revealed that on average, COVID-19 patients in Bogor Regency are people who work in DKI Jakarta. "Recently, the most worrying thing is that every day there are additional positive cases and on average they work in Jakarta," said Ade in an online discussion, Saturday (2/5/2020).

REPUBLIKA.CO.ID, BOGOR - He explained that the district government strongly supports the declaration of a safe COVID-19 village in Tambakan Village. He also appreciated various activities in the village, such as residents producing their own masks. Ade hopes that this activity can be followed by other villages.

\section{Conclusion}

The media gave an image of the Bogor Regent's positive character in dealing with COVID19. These characters include: responsive, creative, disciplined and assertive, analytical, attentive, and anticipatory. Based on the characters described by the media, her leadership style is a transformational leadership style. She is able to optimally transform the various kinds of efforts made to achieve goals according to the targets set in facing the COVID-19 pandemic. Followers or society show a sense of pride, trust, admiration, loyalty to their leaders. The leadership of Ade Munawaroh Yasin also showed changes in attitudes, behaviors, emotions, and community needs for better changes in the future.

\section{References}

[1] Almuttaqi, A. I. Kekacauan Respons terhadap COVID-19 di Indonesia.

[2] Chen, Q., Min, C., Zhang, W., Wang, G., Ma, X., \& Evans, R. (2020). Unpacking the black box: How to promote citizen engagement through government.

[3] Danim, Sudarwan. 2004. Motivasi Kepemimpinan dan Efektivitas Kelompok. Jakarta: Rineka Cipta Utama.

[4] Djalante, R., Lassa, J., Setiamarga, D., Mahfud, C., Sudjatma, A., Indrawan, M., \& Gunawan, L. A. (2020). Review and analysis of current responses to COVID-19 in Indonesia: Period of January to March 2020. Progress in Disaster Science, 100091.

[5] Fairclough, Norman. (1992). Discourse and Social Change. Cambridge: Polity Press. (1995). Media Discourse. London:Longman. Fiske, John. (1990). Introduction to Communication Studies (second edition). London and New York: Routledge.

[6] Hadiwardoyo, W. (2020). Kerugian Ekonomi Nasional Akibat Pandemi COVID19. Baskara: Journal of Business \& Entrepreneurship, 2(2), 83-92.

[7] Hou, C., \& Wu, H. (2020). Rescuer, decision maker, and breadwinner: Women's predominant leadership across the post-Wenchuan earthquake efforts in rural areas, Sichuan, China. Safety science, 125, 104623.

[8] Lafrenière, J., Sweetman, C., \& Thylin, T. (2019). Introduction: gender, humanitarian action and crisis response.

[9] Lin, Q., Zhao, S., Gao, D., Lou, Y., Yang, S., Musa, S. S., ... \& He, D. (2020). A conceptual model for the outbreak of Coronavirus disease 2019 (COVID-19) in Wuhan, China with individual reaction and governmental action. International Journal of Infectious Diseases. 
[10] Lin, Y., Kelemen, M., \& Kiyomiya, T. (2017). The role of community leadership in disaster recovery projects: Tsunami lessons from Japan. International Journal of Project Management, 35(5), 913-924.

[11] Nurhayati, T., \& Aji, R. H. S. (2020). Emansipasi Melawan Pandemi Global: Bukti Dari Indonesia. 'ADALAH, 4(1).

[12] Lestari, Puji (2020). Dampak Positif Pembelajaran Online Dalam Sistem Pendidikan Indonesia Pasca Pandemi COVID-19. 'ADALAH, 4(1).

[13] Rahayu, R. N. (2020). Analisis Berita Hoax COVID-19 Di Media Sosial Di Indonesia. Jurnal Ekonomi, Sosial \& Humaniora, 1(09), 60-73.

[14] Susilo, A., Rumende, C. M., Pitoyo, C. W., Santoso, W. D., Yulianti, M., Herikurniawan, H., \& Chen, L. K. (2020). Coronavirus Disease 2019: Tinjauan Literatur Terkini. Jurnal Penyakit dalam Indonesia, 7(1), 45-67.

[15] Triantoro, Safaria. 2004. Kepemimpinan. Edisi Pertama. Yogyakarta: Graha Ilmu.

[16] Yukl, Gary. 2010. Kepemimpinan dalam Organiasasi. Jakarta: Indeks.

[17] Yunus, N. R., \& Rezki, A. (2020). Kebijakan Pemberlakuan Lock Down Sebagai Antisipasi Penyebaran Corona Virus COVID-19. SALAM: Jurnal Sosial dan Budaya Syar-i, 7(3). 